\title{
A Low Cost Divergent Type Apple Grader for Kashmiri Apples
}

\author{
Mohd. Muzamil*, Junaid Wani, Aaliyah Mustafa, Masrat Mohiuddin, \\ Aayat Mir, Shahzad Faisal and Swati Nirbhavane
}

\author{
Sher-e-Kashmir University of Agricultural Sciences and Technology, Shalimar, \\ $J \& K-190025$, India \\ *Corresponding author
}

\section{A B S T R A C T}

The state of Jammu and Kashmir has the distinction of producing best quality apples with highest proportion among all member states of Indian state. These apples are usually graded by manual labours of all age groups. The heavy reliance on manual labours and their non-availability at peak season has increased the overall cost of apple production. The existing mechanical graders are bulky, costly, imported and non-portable. A low cost motorized portable apple grader was fabricated with feeding hopper, conveying rollers, flow reduction device, main frame, power transmission system and collecting trays. The apples were graded into four grades viz., Grade I- less than $50 \mathrm{~mm}$, Grade II - 50-60 mm, Grade III - 60-70 and Grade IV above $70 \mathrm{~mm}$. The apple grader has overall dimensions of $1460 \mathrm{~mm} \times 842 \mathrm{~mm}$ with a cost of Rs. 12,000. The optimum conditions for the efficient working of apple grader occurred at roller spacing of 56-82 $\mathrm{mm}$ and hopper inclination of 30 degree resulting in a grading efficiency of $84.2 \%$ at $100 \mathrm{rpm}$. The machine has a throughput capacity of $530 \mathrm{Kg}$ per hour. The grader resulted in cost saving of Rs. 1782/per tonne and 17 fold reduction in grading time in comparison to manual method of grading. The cost analysis of grader revealed that break-even point occurred at 424 hours per annum with an annual utility of 225 tonnes and the corresponding pay-back period of apple grader was one year.

\section{Introduction}

Apple is the pomaceous fruit in the rose family (Rosaceae) under Malus domestica species. India is second largest producer of fruits (64 MT) accounting for $10 \%$ of world fruit production (Pawar and Khodke, 2016). The apple production in India is about 2896.6 ('000) MT, constituting about $2.9 \%$ of world apple production. The state of Jammu and
Kashmir (J\&K) has the distinction of producing high quality apples to the tune of 2003.07 metric tonnes, sharing about $69.15 \%$ of total production (Horticulture Statistics Division, 2016). Apple is considered as common entity, consumed on regular basis by people from different cultures and nations (Strapatsa et al., 2006). In post-harvest operations, grading of apples is one of the most critical operation that defines the quality 
market price trading and commercial purpose utilisation. This also ensures fairness to both buyers and sellers. The apple fruit varies in size to a larger extent, even from the same plant and same variety. This variation necessitates the grading of apples after harvesting. Grading is sorting of apples into different grades according to the size, shape, colour and volume to fetch high price in the market. The most common method of grading employed for apples is manual method by using labour of different age groups. The manual method is manifested with low efficiency, costly, slow, time consuming, labour intensive, uneven, requirement of skilled labour and errors in judgement for same apple fruit at different intervals (Narvankar and Jha, 2005). On an average, one skilled labour grades about $200-300 \mathrm{Kg}$ per day. The existing mechanical apple graders have failed to fill the vacuum and ameliorate the problems caused by manual method of apple grading. These graders usually employ complex grading arithmetic's like fuzzy logic (Kavdir and Guyer, 2003), image processing (Rosli et al., 2012), artificial neural network (Jhuria et al., 2013), computer vision (Ohali, 2011), multi-class kernel support vector (Zhang and $\mathrm{Wu}, 2012$ ) and colour mapping (Dah-Jye-Lee et al., 2011). They are very costly, imported, bulky, requires large areas, non- portable and need technical skills for their operation and maintenance. A divergent roller mechanism was developed to test evaluate the fruit grading based on size for sapota (Patil and Patil, 2002), onion (Anonymous, 2003) and lemon (Nevkar, 1990). The divergent roller grading method is fast, accurate and causes little damage with appropriate insulation material in comparison to other methods of grading of fruits (Ukey and Unde, 2010).

Therefore, a study was carried out to design and develop a low cost motorized divergent roller type apple grader to find the solution of the problems due to manual apple grading in order to reduce the grading cost responsible for increasing the cost of production of apples.

\section{Materials and Methods}

\section{Measurement of physical parameters}

The design of the machine necessitates the determination of physical dimensions of apples. A sample of Golden Delicious apple variety was selected and their length and diameter were measured with the help of Vernier Calliper with $0.001 \mathrm{~mm}$ accuracy. The mean length, width and sphericity were found to be $61.0 \mathrm{~mm}, 67.08 \mathrm{~mm}$ and 1.06, respectively (Table 1).

$$
\text { Sphericity }=\frac{(l * b * t)^{\frac{1}{3}}}{l}
$$

\section{Fabrication of components of machine}

A divergent roller type apple grader was designed and developed in the workshop of college of agricultural engineering, SKUAST$\mathrm{K}$, Shalimar in 2017-18. The basic structure comprised of feeding hopper, conveying rollers, main frame, power transmission system and collecting trays (Fig. 1).

\section{Feeding hopper}

The feeding hopper was designed and developed in trapezoidal shape to provide feasible conditions for easy movement of apples towards grading/conveying rollers. The hopper was made from 20 gauge G.I. sheet. The dimensions of the feeding unit were 682 $\mathrm{mm} \times 470 \mathrm{~mm}$ x $2 \mathrm{~mm}$ (Table 2). The inclination of the feeding hopper was made adjustable to accommodate different varieties of apples. An insulating material with soft cloth was fixed over the hopper to avoid bouncing and damage to the surface of apple. 


\section{Grading/conveying unit}

The grading unit consisted of main frame, conveying/grading rollers and flow reduction device (stopper). The main frame was designed in rectangular shape (1460 $\mathrm{mm} \times 842$ $\mathrm{mm} \times 50 \mathrm{~mm}$ ) to provide a support to grading/conveying rollers. The grading/conveying rollers have a diameter of $50 \mathrm{~mm}$ and length of $1250 \mathrm{~mm}$.

The rollers were coated with smooth insulating material to prevent the damage to the surface of apples. The two pairs of grading rollers were placed side by side on the main frame exactly below the end of feeding hopper. The grading/conveying rollers were rotated by belt and pulley arrangement provided at the rear end while feed end was attached on revolving bearings of $30 \mathrm{~mm}$ diameter. The gap between the rollers was made adjustable to accommodate apples of different varieties.

\section{Power transmission unit}

A power transmission unit was placed below the main frame and consists of belt-pulley mechanism and speed reduction unit. The rollers of grading were driven by 1 HP electric motor through belt and pulley mechanism. The reduction in the speed was necessary to ensure the easy movement of apples over the grading rollers. The reduction was achieved by using different diameter pulleys.

\section{Collecting trays}

The diverging action of grading/conveying rollers from feed end to rear end allowed the fruits to grade into four different sizes. The graded fruits fell downwards towards the collection platform. The platform was partitioned into four rectangular compartments, each having a dimension of $535 \mathrm{~mm} \times 340 \mathrm{~mm} \times 2 \mathrm{~mm}$ from feed end.
The dividers were provided in between to grade the apples into different sizes. The collection trays were cushioned to prevent the damage to apples due to impact during collection.

\section{Test procedure}

The developed prototype (Fig. 2) was tested for apple (Golden Delicious) at three roller spacing (54-78 mm, 56-82 $\mathrm{mm}$ and 58-86 $\mathrm{mm})$ and feeding hopper inclination $\left(25^{\circ}, 30^{\circ}\right.$ and $35^{\circ}$ ). The response parameters were measured in terms of grading efficiency (\%) and time of grading (s) (Table 3). The preliminary experiments revealed that roller speed of $100 \mathrm{rpm}$ ensured smooth flow of apples from feed end to rear end. Therefore, the speed was kept constant at $100 \mathrm{rpm}$. The time required for grading and weight at each combination was recorded to calculate the capacity of the developed prototype of apple grader.

The mean diameter of the apples collected in a particular grade was compared to grade gap range in order to decide whether the apples are under or over the gap range. The test was replicated three times and average grading efficiency was calculated. The grading efficiency was calculated by using relationship given (Singh, 1980).

Grading efficiency $(\%)={ }^{\frac{G_{t}-G_{m}}{G_{t}}} \times 100$
Where,

$\mathrm{G}_{\mathrm{t}}=$ Total number of apples; $\mathrm{G}_{\mathrm{m}}=$ Total number of misclassified apples

\section{Results and Discussion}

The results of the experiments in terms of response parameters (Table 3) at different spacing of rollers and inclination angle of hopper have been discussed. 
Table.1 Physical dimensions of apple relevant to apple grader design

\begin{tabular}{|l|c|c|c|c|}
\hline Variety & Length, $\mathbf{l}(\mathbf{m m})$ & Width, b $(\mathbf{m m})$ & Thickness, $\mathbf{t}(\mathbf{m m})$ & Sphericity \\
\hline Golden Delicious & 55 & 66 & 63.7 & 1.10 \\
\hline & 58 & 63 & 64.1 & 1.06 \\
\hline & 54 & 60 & 61.2 & 1.07 \\
\hline 59 & 58 & 59.1 & 0.99 \\
\hline & 47 & 52 & 53.2 & 1.07 \\
\hline 58 & 64 & 64.9 & 1.07 \\
\hline & 62 & 71 & 70.3 & 1.09 \\
\hline & 70 & 75 & 74.2 & 1.04 \\
\hline & 68 & 72 & 71.3 & 1.03 \\
\hline & 63 & 77 & 76.4 & 1.14 \\
\hline Average & 70 & 74 & 73.1 & 1.05 \\
\hline
\end{tabular}

*values are average of five

Table.2 Specifications of developed prototype of apple grader

\begin{tabular}{|l|}
\hline Components \\
\hline Feeding hopper \\
\hline Grading/conveying rollers \\
\hline Main frame \\
\hline Power transmission unit \\
\hline Collecting trays \\
\hline
\end{tabular}

\begin{tabular}{l} 
Design values \\
$682 \mathrm{~mm} \times 470 \mathrm{~mm} \times 2 \mathrm{~mm}$ \\
\hline $\begin{array}{l}\text { Diameter }=50 \mathrm{~mm} \\
\text { Length }=1250 \mathrm{~mm}\end{array}$ \\
$1460 \mathrm{~mm} \times 842 \mathrm{~mm} \times 50 \mathrm{~mm}$ \\
$1 \mathrm{HP}$ electric motor \\
$\begin{array}{l}\text { Number of compartments }=4 \\
(535 \mathrm{~mm} \times 340 \mathrm{~mm} \times 2 \mathrm{~mm})\end{array}$
\end{tabular}

Table.3 Plan of experiment

\begin{tabular}{|c|}
\hline Variables \\
\hline Spacing of rollers \\
\hline Hopper inclination \\
\hline
\end{tabular}

Levels
$3(54-78 \mathrm{~mm}, 56-82 \mathrm{~mm}$ and $58-86 \mathrm{~mm})$
$3\left(25^{\circ}, 30^{\circ}\right.$ and $\left.35^{\circ}\right)$

Responses
Grading efficiency (\%)
Time of grading (s)

Table.4 ANOVA for grading efficiency and time of grading

\begin{tabular}{|c|c|c|c|c|c|c|}
$\begin{array}{c}\text { S. } \\
\text { No. }\end{array}$ & Parameters & $\begin{array}{c}\text { Main effect (p- values) } \\
\text { Roller } \\
\text { spacing }\end{array}$ & $\begin{array}{c}\text { Hopper } \\
\text { inclination }\end{array}$ & $\begin{array}{c}\text { Interaction effect (poller } \\
\text { spacing) }\end{array}$ & $\begin{array}{c}\text { (Hopper } \\
\text { inclination) }\end{array}$ & $\begin{array}{c}\text { Rolles spacing* } \\
\text { Hopper inclination }\end{array}$ \\
\hline 1. & $\begin{array}{c}\text { Grading } \\
\text { Efficiency }\end{array}$ & $<0.0001^{*}$ & 0.2005 & $<0.0001^{*}$ & 0.0910 & 0.2918 \\
\hline 2. & $\begin{array}{c}\text { Time of } \\
\text { Grading }\end{array}$ & 0.9897 & $<0.0001^{*}$ & 0.0234 & 0.0028 & 0.6480 \\
\hline
\end{tabular}


Table.5 Optimum conditions for the operation of prototype of apple grader

\begin{tabular}{|c|c|c|c|c|c|c|}
\hline S. No. & $\begin{array}{c}\text { Roller } \\
\text { spacing } \\
(\mathbf{m})\end{array}$ & $\begin{array}{c}\text { Hopper } \\
\text { inclination } \\
\text { (degree) }\end{array}$ & $\begin{array}{c}\text { Grading } \\
\text { efficiency } \\
(\%)\end{array}$ & Time (s) & Desirability & Result \\
\hline $\mathbf{1}$ & $56-82$ & 30 & 84.2 & 17.1 & 0.941 & Selected \\
\hline
\end{tabular}

Table.6 Cost comparison of manual and mechanical apple grading

\begin{tabular}{|c|c|c|c|}
\hline Method/Cost & \multicolumn{2}{|c|}{ Details } & Cost, Rs. \\
\hline \multicolumn{4}{|l|}{ Manual grading } \\
\hline & Fixed charges & Nil & Nil \\
\hline & Variable charges & $\begin{array}{c}1 \text { skilled labour } 250 \mathrm{Kg} \text { per } \\
\text { day }\end{array}$ & 500 per day \\
\hline \multirow{2}{*}{ 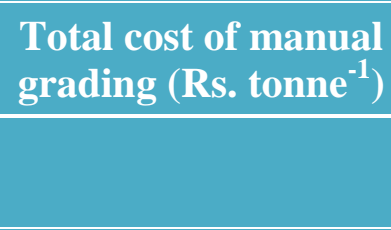 } & & & 2000 \\
\hline & $\begin{array}{l}\text { Capacity of manual grading } \\
\qquad\left(\mathrm{Kg} \cdot \mathrm{h}^{-1}\right)\end{array}$ & & 31.25 \\
\hline \multirow[t]{7}{*}{ Mechanical grading } & \multicolumn{2}{|c|}{ Fixed cost } & \\
\hline & 1.Depreciation (Rs. $\left.\mathrm{h}^{-1}\right)$ & $\begin{array}{c}@ 10 \% \text { salvage value, life }= \\
8 \text { years, working hours }=500 \\
\text { hours }\end{array}$ & 2.7 \\
\hline & $\begin{array}{l}\text { 2.Interest on investment } \\
\qquad\left(\text { Rs. } \mathrm{h}^{-1}\right)\end{array}$ & Interest @ 16\% & 2.11 \\
\hline & Total Fixed cost $\left(\right.$ Rs. $\left.h^{-1}\right)$ & $\begin{array}{c}\text { Depreciation }+ \text { Interest on } \\
\text { investment }\end{array}$ & 4.81 \\
\hline & \multicolumn{2}{|l|}{ Variable cost } & \\
\hline & $\begin{array}{l}\text { 1. Repair and maintenance } \\
\text { 2.Labour charges } \\
\text { 3.Electricity }\end{array}$ & $\begin{array}{c}@ 2 \% \text { of initial cost } \\
1 \text { labour @500 per day } \\
\text { @8 per day }\end{array}$ & $\begin{array}{l}0.48 \\
62.5 \\
47.7\end{array}$ \\
\hline & \multicolumn{2}{|c|}{ Capacity of machine $\left(\mathrm{Kg} \cdot \mathrm{h}^{-1}\right)$} & 530 \\
\hline $\begin{array}{l}\text { Total cost of } \\
\text { mechanical grading } \\
\left(\text { Rs. tonne }{ }^{-1}\right)\end{array}$ & & & 218 \\
\hline
\end{tabular}

Ratio of cost of manual and mechanical grading was 2000: $218=9: 1$ 
Table.7 Capability of material handling of apple grading

\begin{tabular}{l|l|l|}
$\begin{array}{l}\text { Apple } \\
\text { grader }\end{array}$ & Attributes & Value \\
& Capacity $\left(\mathrm{Kg} \cdot \mathrm{h}^{-1}\right)$ & 530 \\
& Annual Utility (tonnes per annum) & 225 \\
\cline { 2 - 3 } & Break-even point (hours per annum) & 424 \\
\cline { 2 - 3 } & Pay-back period (year) & 1
\end{tabular}

Fig.1 Conceptual model of apple grader

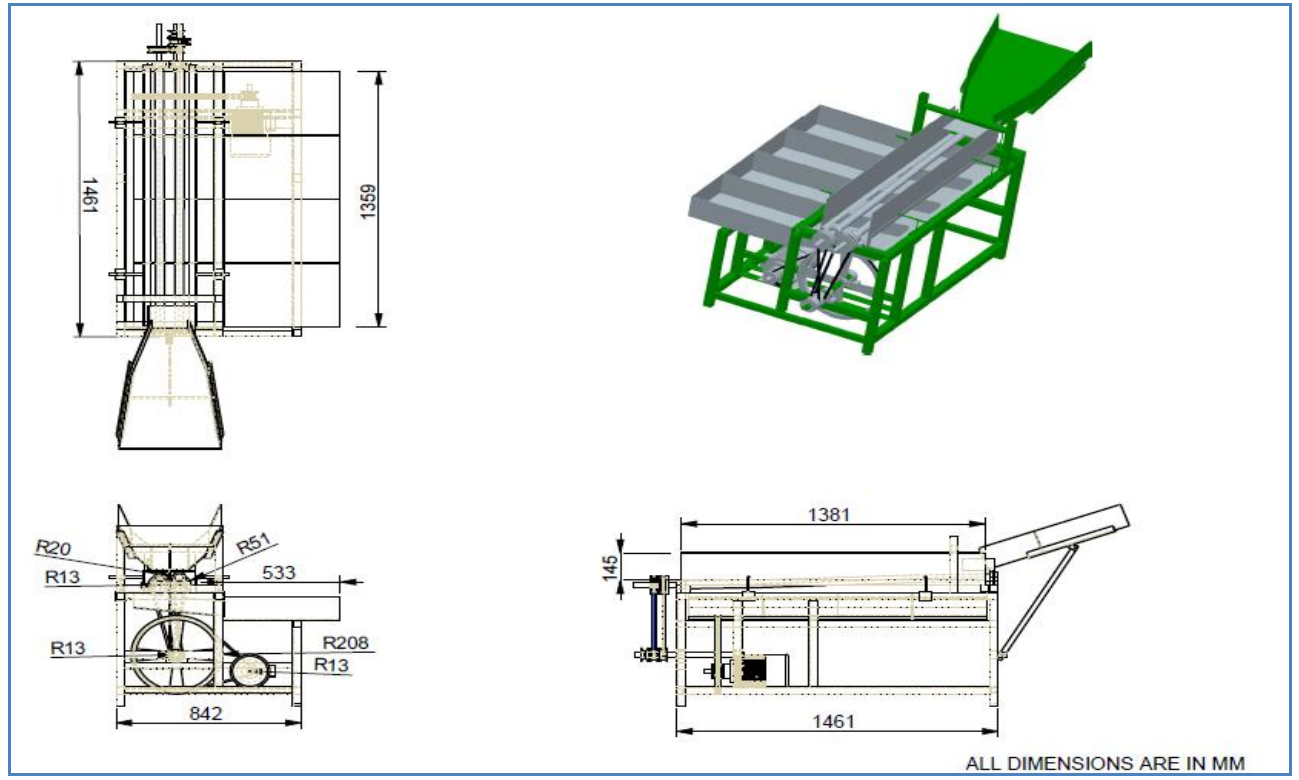

Fig.2 Prototype of divergent roller type apple grader

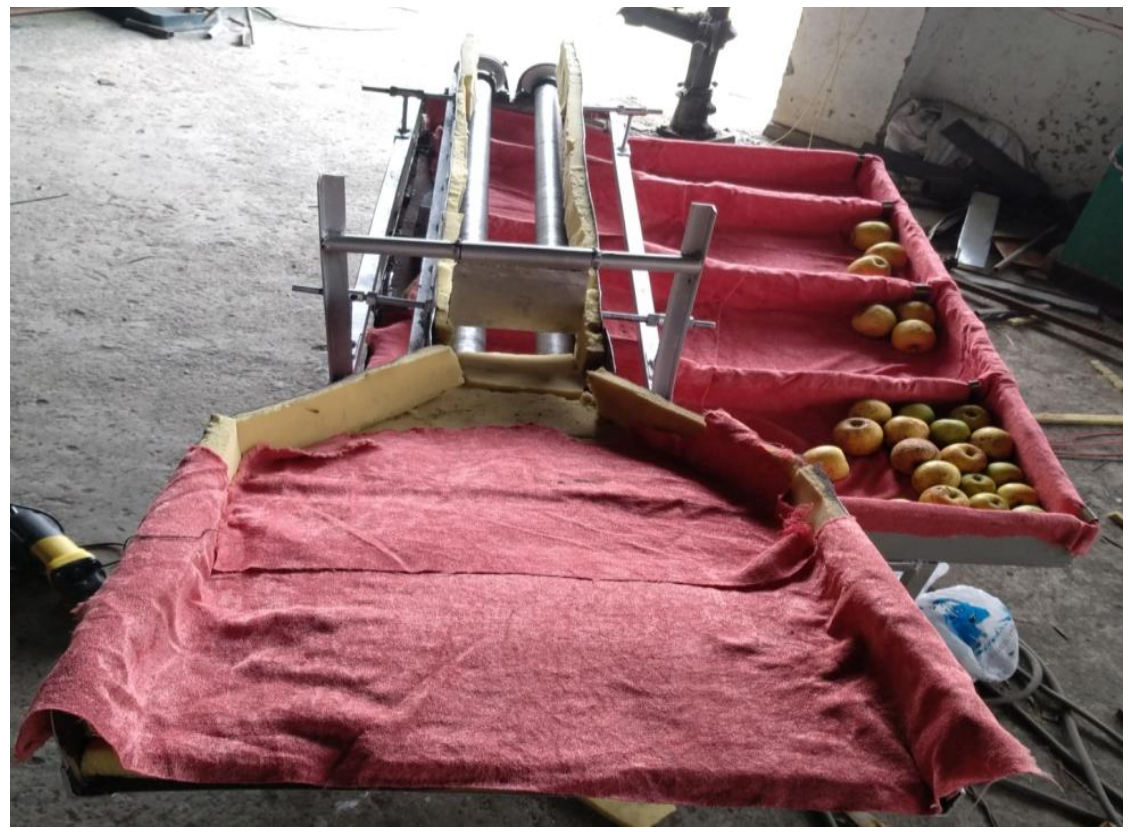


Fig.3 Effect of roller spacing on grading efficiency

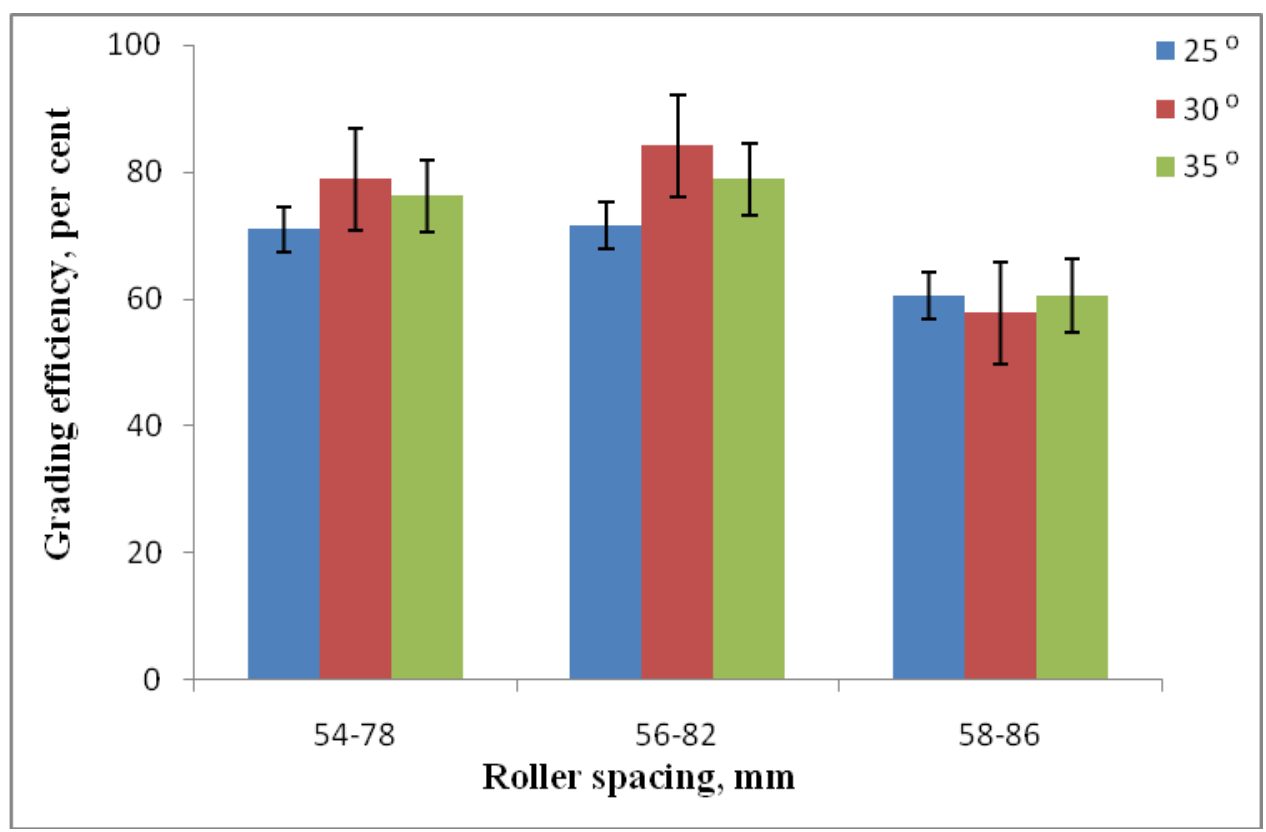

Fig.4 Variation in grading time by hopper inclination angle

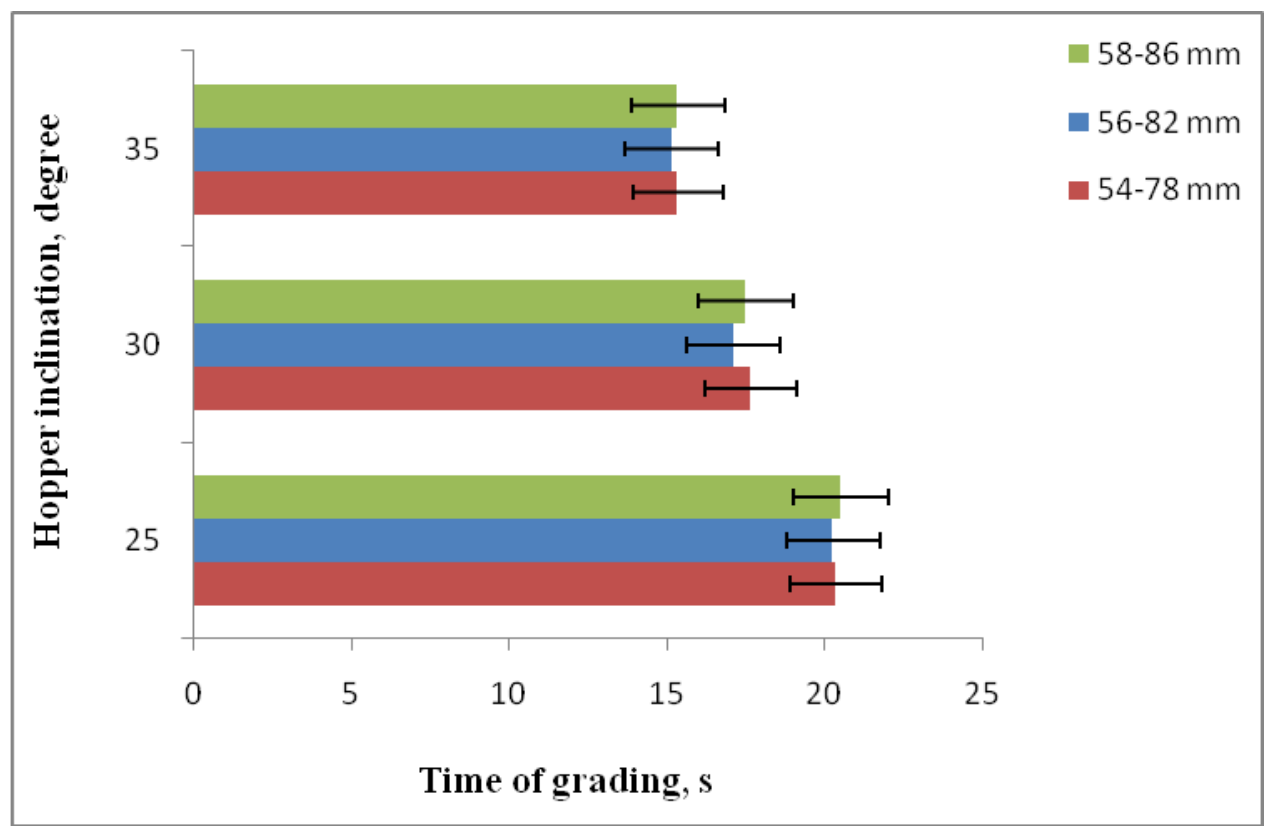
Effect of roller spacing on grading
efficiency

The grading efficiency increased with the increase in roller spacing from $54-78 \mathrm{~mm}$ to $56-82 \mathrm{~mm}$ and then decreased with the increase in roller spacing to $58-86 \mathrm{~mm}$ for all hopper inclination angles (Fig. 3). The maximum grading efficiency of $84.2 \%$ occurs at roller spacing of $56-82 \mathrm{~mm}$ at hopper inclination of $30^{\circ}$. The minimum grading efficiency of $57.9 \%$ occurs at roller 
spacing of $58-86 \mathrm{~mm}$ at same hopper inclination angle of $30^{\circ}$. The capacity of the developed prototype of apple grader was found to be $530 \mathrm{Kg}$ per hour.

The statistical analysis of the results by design expert 10.0 confirmed that roller spacing significantly influences the grading efficiency at $1 \%$ level of significance. The effect of feeding hopper inclination was nonsignificant at $1 \%$ level of significance (Table 4).

\section{Effect of hopper inclination on grading time}

The variation in time of grading of apples from feeding hopper to collecting trays at different roller spacing is shown in Figure 4. The grading time of apples increased with the reduction in hopper inclination angle from 3525 degree. It was observed that higher inclination of feeding hopper angle results in higher velocity of apples on grading/conveying rollers, thereby resulting in less time of grading. The trend was observed at all roller spacing. The time of grading varied from 15.15 to 20.5 seconds. The statistical analysis revealed that time of grading is significantly affected by hopper inclination angle at $1 \%$ level of significance (Table 4).

\section{Optimum conditions for the operation of the prototype of apple grader}

The observed data was analysed to determine the optimum conditions that will ensure the most favourable conditions for the working of the developed prototype of apple grader to attain maximum efficiency. The statistical analysis by design expert 10.0 revealed that optimum conditions occurred at roller spacing of 56-82 $\mathrm{mm}$ and hopper inclination of 30 degree with a desirability index of 0.941 (Table 5).

\section{Cost economics of apple grading}

Cost economics and comparison with manual method of apple grading was determined and shown in Table 6 . The cost of manual grading was found to be Rs. 2000 per tonne and mechanical grading as Rs. 218 per tonne. The machine costs Rs. 12000. The machine resulted in saving of Rs. 1782.0 in comparison to manual method of apple grading. It also ensured timeliness of operation by reducing the time 17 times than manual method. The break-even point occurs at 424 hours per annum with capability to handle about 225 tonnes per annum. The payback period of apple grader is one year (Table 7).

In conclusion, the divergent roller type apple grader worked efficiently in sorting the apples into different categories on the basis of their size and shape. The grading efficiency varied from $57.9-84.2 \%$. The optimum conditions occurred at a roller spacing of $56-82 \mathrm{~mm}$, hopper inclination of $30^{\circ}$, roller speed of 100 rpm resulting in grading efficiency of $84.2 \%$ and time of grading of 17.1 seconds. The throughput capacity of the machine was 530 $\mathrm{Kg} \cdot \mathrm{h}^{-1}$ in continuous operation. The machine results in cost saving of Rs. 1782.0 and 17 fold reduction in grading time in comparison to manual method of apple grading. The break-even point of the machine occurred at 424 hours per annum with annual utility of 225 tonnes. The pay-back period rests within one year.

\section{Acknowledgements}

We are highly indebted to staff members of SKUAST-K, Shalimar (College of Agricultural Engineering) for their guidance and constant supervision as well as for providing facilities and necessary information regarding the project. We are highly thankful to workers of divisional workshop of college 
of Agricultural engineering for their support in completing the project.

\section{References}

Anonymous, 2003. Design and development of divergent roller type onion grader. Rajgurunagar, Pune, Journal of Agricultural Engineering, Technical bulletin No. 6.

Dah-Jye, L., J. K. Archibald and Xiong, G. 2011. Rapid Color Grading for Fruit Quality Evaluation Using Direct Color Mapping. IEEE Transactions on Automation science and Engineering 8(2): 292-302.

Horticulture Statistics Division, Department of Agriculture, Cooperation and farmers welfare, 2016.

Jhuria, M., A. Kumar and Borse, R. 2013. Image processing for Smart Farming: Detection of disease and Fruit Grading. Proceeding of the 2023 IEEE second international conference on image processing (ICIIP).

Kavdir, U., and Guyer, D. E. 2003. Apple Grading Using Fuzzy Logic. Turkish Journal of Agriculture and Forestry 27: 375-382.

Narvankar, D. S., and Jha, S. K. 2005. Development of rotating screen grader for selected orchard crops. Journal of Agricultural Engineering 42 (4): 60-64.

Nevkar, G. S. 1990. Development and performance testing of divergent roller type fruit sorting machine. M. Tech. Thesis, Mahatma Phule Krishi Vidyapeeth, Rahuri, Ahmednagar, M.S.

Ohali, Y. A. 2011. Computer vision based date fruit grading system: Design and implementation. Journal of King Saud University - Computer and Information Science 23: 29-36.

Patil, V. B., and Patil, J. S. 2002. Design, development and performance testing of grader for sapota fruits. B. Tech. Thesis, Mahatma Phule Krishi Vidyapeeth, Rahuri, Ahmednagar, M.S. (India).

Pawar, S. G., and Khodke, S. U. 2016. Design and development of grader for Kagzilime. International Journal of Agricultural Engineering 9(1): 12-18.

Rosli, B. R., Othman, M. B., Bakar, M. N., K. A. Ahmad and Mansor, R. 2012. Mango Grading By Using Fuzzy Image Analysis. 2012. International Conference on Agricultural, Environment and Biological Sciences (ICAEBS'2012) May p. 26-27.

Singh, B. 1980. Development and performance of different belt speed expanding pitch type potato grader. Journal of Agricultural Engineering 17 (2): 69.

Strapatsa, A, V., G. D. Nanos and Tsatsarelis, C. A. 2006. Energy flow for integrated apple production in Greece. Agriculture Ecosystem and Environment 116: 176180.

Ukey, P. D., and Unde, P. 2010. Design, development and performance evaluation of sapota fruit grader. International Journal of Agricultural Engineering 3(1): 35-39, 62-64.

Zhang, Y., and Wu, L. 2012. Classification of Fruits Using Computer Vision and a Multiclass Support Vector Machine. Sensors 12: 12489-12505.

\section{How to cite this article:}

Mohd. Muzamil, Junaid Wani, Aaliyah Mustafa, Masrat Mohiuddin, Aayat Mir, Shahzad Faisal and Swati Nirbhavane. 2018. A Low Cost Divergent Type Apple Grader for Kashmiri Apples. Int.J.Curr.Microbiol.App.Sci. 7(04): 3561-3569. doi: https://doi.org/10.20546/ijcmas.2018.704.401 